\title{
Potret Supervisi Akademik Kepala Sekolah Di SMK Negeri 1 Kota Jambi
}

\author{
Mohamad Muspawi, Bradley Setiyadi, Ratih Elvirawati \\ Universitas Jambi, Indonesia \\ *Corresponding Author: mohamad.muspawi@unja.ac.id
}

\begin{abstract}
ABSTRAK
Penelitian bertujuan untuk mengetahui dan mendeskripsikan bagaimana implementasi supervisi akademik oleh kepala sekolah di Sekolah Menengah Kejuruan (SMK) Negeri 1 Kota Jambi. Menggunakan metode kualitatif deskriptif dengan jenis penelitian studi kasus (case study). Subjek penelitian adalah kepala sekolah, wakil kepala sekolah bidang kurikulum, dan masing-masing guru yang mewakili setiap program keahlian. Penentuan subjek penelitian menggunakan Purposive Sampling. Teknik pengumpulan data menggunakan metode wawancara. Teknik analisis data menggunakan reduksi data, penyajian data, dan penarikan kesimpulan. Hasil penelitian menunjukkan bahwa: (1) Ditinjau dari aspek perencanaan supervisi akademik, kepala sekolah belum optimal melibatkan seluruh elemen guru dalam perencanaan program supervisi akademik, sehingga guru kurang mengetahui tujuan, sasaran, metode, pendekatan, dan tindak lanjut seperti apa yang akan diberikan dan ingin dicapai. (2) Ditinjau dari aspek pelaksanaan supervisi akademik, kepala sekolah jarang terjun langsung dalam mensupervisi ke kelas-kelas. Pelaksanaan supervisi akademik di sekolah ini juga belum merata. Disamping itu, pelaksanaan supervisi akademik di ini khususnya dalam kurun waktu satu tahun terakhir terhitung sejak pandemi Covid-19 dilakukan secara daring dengan fokus pada administrasi dan kehadiran guru saja. (3) Ditinjau dari aspek tindak lanjut supervisi akademik, kepala sekolah telah memberikan umpan balik atau tindak lanjut yang cukup baik terhadap hasil supervisi. Hal ini dibuktikan dengan telah dilakukannya diskusi akhir oleh kepala sekolah dengan mengajak guru berdiskusi terkait permasalahan yang dihadapi ketika mengajar. Selain itu, kepala sekolah turut memberikan pembinaan dengan mengikutsertakan guru-guru dalam berbagai kegiatan workshop dan pelatihan baik yang dilakukan secara internal maupun secara eksternal. Berdasarkan hasil penelitian dapat disimpulkan bahwa implementasi supervisi akademik kepala sekolah di SMK Negeri 1 Kota Jambi sudah cukup baik namun belum optimal.
\end{abstract}

Kata Kunci: Implementasi, Supervisi Akademik

\section{PENDAHULUAN}

Dewasa ini, era globalisasi mendorong kemajuan Ilmu Pengetahuan dan Teknologi (IPTEK) menjadi semakin pesat. Tentunya hal tersebut menuntut agar Sumber Daya Manusia (SDM) mampu bersaing dan mengimbangi zaman yang semakin berkembang ini. Untuk mewujudkan SDM yang mampu bersaing tersebut, tentunya dibutuhkan pendidikan yang berkualitas. Namun saat ini, kualitas pendidikan masih menjadi salah satu problematika pendidikan di Indonesia. Pendidikan mempunyai kedudukan yang sangat strategis dalam membentuk dan menentukan kualitas SDM. Oleh karenanya sangat diperlukan sistem pendidikan yang mampu melahirkan manusia seutuhnya, yakni sistem pendidikan yang memandang mutu sebagai salah satu tujuan dari pendidikan.

Menanggapi permasalahan tersebut, pemerintah telah berupaya dengan mengarahkan berbagai macam kebijakan pendidikan pada upaya-upaya yang meningkatkan kualitas 
pendidikan yaitu yang mampu menghasilkan SDM yang handal. Pemerintah juga telah menjabarkan tujuan pendidikan nasional ke dalam peraturan, kurikulum, program, maupun sarana dan prasarana sebagai fasilitas dalam pelaksanaan pendidikan dan pembelajaran di sekolah. Dalam upaya meningkatkan mutu pendidikan, banyak variabel dan aspek yang harus diperhatikan oleh pemerintah. Variabel tersebut dapat dilihat salah satunya dari tugas kepala sekolah dalam memanajemen sekolah. Adapun peran kepala sekolah menurut Mulyasa (2013) adalah sebagai educator, manajer, administrator, supervisor, leader, innovator, motivator (EMASLIM). Diantara peran kepala sekolah tersebut, salah satu peran yang tak kalah penting adalah peran sebagai supervisor.

Sebagai penyelenggara pendidikan di sekolah, kepala sekolah memiliki pengaruh yang besar pada peningkatan mutu proses pembelajaran, baik melalui pelaksanaan supervisi yang efektif maupun kebijakan dalam meningkatkan kompetensi para pendidik (Suharsaputra, 2018). Dalam upaya memastikan pembelajaran berjalan efektif dan bermutu, perlu dilakukan upaya-upaya membantu guru dalam mengembangkan dan meningkatkan mutu proses pembelajaran. Supervisi akademik oleh kepala sekolah menjadi hal yang sangat penting dalam upaya tersebut. Suharsaputra (2018) mengemukakan supervisi sebagai layanan yang diberikan kepada pendidik dalam rangka meningkatkan kualitas pembelajaran dan memperbaikinya, sesuai dengan hasil observasi yang dilangsungkan oleh kepala sekolah pada kegiatan pembelajaran yang dilaksanakan di dalam kelas.

Kepala Sekolah sebagai supervisor pendidikan memiliki kewajiban untuk membina para guru supaya menjadi pengajar yang baik. Untuk guru yang sudah baik dapat dipertahankan kualitasnya dan untu guru yang belum baik dapat ditingkatkan menjadi lebih baik. Sementara itu, semua guru baik yang sudah berkompeten maupun yang masih kurang kompeten agar dapat terus dibina supaya tidak ketinggalan zaman terutama dalam proses pembelajaran maupun materi yang diajarkan. Sebab guru sebagai agen pendidikan harus senantiasa mengembangkan dan memperbaharui keilmuannya secara berkesinambungan guna memenuhi tuntutan zaman. Adapun tujuan dari kegiatan supervisi ini tak lain adalah untuk membantu guru mengembangkan kapabilitasnya dalam mengelola pembelajaran serta membantu guru dalam menumbuhkan motivasi, sehingga keterampilan mengajar guru dapat ditingkatkan.

Guru merupakan bagian yagn sangat penting dalam proses pendidikan karena guru berperan sebagai salah satu penentu keberhasilan pendidikan. Maka dari itu, untuk mewujudkan mutu pendidikan yang berkualitas, terlebih dahulu perlu adanya upaya untuk meningkatkan mutu guru melalui pemberian bantuan dan bimbingan sebagai upaya untuk meningkatkan keterampilan dan kemampuan yang dimiliki guru. Dalam Peraturan Pemerintah No. 19 Tahun 2005 tentang Standar Nasional Pendidikan Pasal 28 ayat (3) disebutkan bahwasanya kompetensi yang harus dimiliki guru meliputi: kompetensi pedagogik, kepribadian, profesional, dan sosial.

Seorang pendidik, dalam hal profesionalisme, haruslah menguasai keterampilan mengajar yang meliputi: keterampilan membuka dan menutup pelajaran, keterampilan bertanya, keterampilan memberi penguatan, dan keterampilan mengadakan variasi mengajar. Wijaya (1994) dikutip dari Zainal (2012) menyatakan bahwa kemampuan profesional yang harus dimiliki guru dalam proses belajar mengajar adalah: (1) menguasai bahan, (2) mengelola program belajar mengajar, (3) mengelola kelas, (4) menggunakan media sumber, (5) menguasai landasan-landasan kependidikan, (6) mengelola interaksi belajar mengajar, (7) menilai prestasi peserta didik untuk kepentingan pengajaran, (8) mengenal fungsi dan program pelayanan bimbingan dan penyuluhan, (9) mengenal dan menyelenggarakan administrasi sekolah, dan (10) memahami prinsip-prinsip dan menafsirkan hasil-hasil penelitian pendidikan guna keperluan pengajaran.

Kompetensi-kompetensi tersebut memiliki tujuan untuk: (1) mengembangkan 
keterampilan bertanya bagi guru agar proses belajar mengajar tidak berlangsung monoton dan tidak hanya terjadi interaksi satu arah, (2) mengembangkan kemampuan guru dalam memanajemen kelas, (3) mengembangkan keterampilan guru dalam mengadakan variasi mengajar, terutama variasi penggunaan media, variasi pandangan dan perhatian, serta variasi penggunaan metode mengajar, dan (4) mengembangkan keterampilan guru dalam menjelaskan materi yang diajarkan.

Berdasarkan observasi dan wawancara awal, diasumsikan bahwa kepala sekolah belum optimal dalam melaksanakan supervisi akademik. Hal ini dibuktikan dari masih terdapatnya sebagian guru yang jarang disupervisi. Selain itu, ketersediaan waktu kepala sekolah menjadi salah satu fakor yang menyebabkan supervisi akademik belum optimal. Supervisi akademik menjadi salah satu faktor yang mempengaruhi kualitas mengajar guru yang dalam hal ini adalah keterampilan mengajar guru. Oleh sebab itu, jika ditinjau dari keterampilan mengajarnya, masih terdapatnya guru yang belum begitu aktif dalam menggunakan media pembelajaran. Hal ini dapat dibuktikan dengan masih terdapatnya guru yang kesulitan merancang pembelajaran secara online dikarenakan gagap teknologi (Gaptek) sehingga pada akhirnya pun guru hanya sekadar memberi tugas tanpa memberikan penjelasan terhadap materi ajar yang diberikan.

Ditinjau dari segi metode ajar, ditemukan permasalahan bahwa sebagian pendidik disinyalir tidak kreatif dalam menentukan metode ajar sehingga pembelajaran terkesan monoton dan tidak tepat sasaran. Disamping itu, kemampuan guru dalam menyampaikan/menjelaskan materi juga terkesan monoton sehingga pembelajaran menjadi membosankan dan minat belajar siswa menjadi menurun. Hal ini dikarenakan masih kurangnya keterampilan guru dalam mengemas pembelajaran atau menjelaskan materi pelajaran secara menarik kepada siswa.

Ditinjau dari segi proses pelaksanaan pembelajaran pun, guru juga masih kurang dalam mengelola kelas sehingga mengakibatkan siswa kurang fokus dalam belajar. Selain itu, sarana dan prasarana yang belum memadai turut menghambat guru dalam proses pembelajaran. Contohnya: ketersedian buku ajar yang belum memadai serta penyediaan proyektor/Infokus di SMK Negeri 1 Kota Jambi masih kurang dan belum memadai sehingga mengharuskan baik itu guru maupun peserta didik untuk bergantian menggunakannya dengan kelas lain. Hal ini tentunya menyebabkan guru terkendala dalam menyampaikan materi yang memerlukan proyektor/Infokus dalam proses pembelajarannya.

Berdasarkan uraian permasalahan yang telah disampaikaan, tentunya perihal supervisi oleh kepala sekolah menjadi hal yang menarik untuk diteliti. Oleh karenanya, peneliti tertarik untuk mengkaji lebih dalam mengenai penerapan supervisi akademik oleh kepala sekolah di SMK 1 Kota Jambi.

\section{METODE PENELITIAN}

Pendekatan dalam penelitian ini adalah menggunakan pendekatan deskriptif kualitatif. Pendekatan deskriptif kualitatif merupakan pendekatan yang dilakukan mengamati orang dalam kehidupan sehari-hari dalam situasi wajar, berinteraksi bersama mereka, melakukan wawancara serta berusaha memaknai bahasa, kebiasan, dan perilaku yang berhubungan dengan fokus penelitian (Moleong, 2014). Sugiyono (2016) mengemukakan bahwa pendekatan deskriptif kualitatif sebagai metode yang menggambarkan dan menganalisis suatu fenomena, kebiasaan, maupun perilaku dari seseorang ataupun sekelompok individu.

Creswell (2013) menyatakan bahwa metode kualitatif ialah metode-metode penelitian yang digunakan untuk mengeksplorasi dan memahami makna dan masalah sosial atau kemanusiaan dari sejumlah individu atau sekelompok orang. Proses penelitian kualitatif ini melibatkan upaya-upaya seperti mengajukan pertanyaan-pertanyaan dan prosedur-prosedur, serta melakukan pengumpulan data spesifik dari para partisipan. Adapun alasan peneliti 
memilih menggunakan pendekatan ini adalah dikarenakan peneliti ingin menggambarkan dan mendeskripsikan seperti apa permasalahan dalam penelitian ini secara sistematis dan tentunya berlandaskan dengan data yang akurat dan apa adanya sehingga tujuan penelitian ini dapat tercapai.

Penelitian ini menggunakan jenis penelitian studi kasus (case study). Menurut Creswell (2013) studi kasus merupakan jenis penelitian dimana peneliti menyelidiki dengan cermat suatu program, peristiwa, aktivitas, proses, atau sekelompok individu. Jenis penelitian dengan studi kasus ini bertujuan untuk mengungkapkan kejadian atau fakta, keadaan, fenomena, variabel dan keadaan yang terjadi saat penelitian berlangsung dengan menyuguhkan apa yang sebenarnya terjadi.

\section{Data dan Sumber Data}

Data dan sumber data yang peneliti gunakan adalah:

a. Data primer, yaitu data yang dihimpun secara langsung dari informan di lapangan yaitu melalui wawancara mengenai implementasi supervisi akademik kepala sekolah di SMK Negeri 1 Kota Jambi. Adapun yang menjadi sumber data utama dalam penelitian ini adalah kepala Sekola dan guru.

b. Data sekunder, yaitu data-data atau dokumen-dokumen yang mendukung penelitian ini seperti misalnya, dokumen tentang profil sekolah, daftar tenaga pendidik dan tenaga kependidikan, jumlah siswa, rombongan belajar, dan dokumen lain yang terkait penelitian ini.

\section{Subjek Penelitian}

Subjek penelitian dipilih dengan menggunakan teknik sampling yaitu "Purposive Sampling". Sugiyono (2014) mengemukakan purposive sampling sebagai teknik penentuan sample penelitian yang menetapkan kriteria-kriteria tertentu atau pertimbangan tertentu sehingga data yang diperoleh representatif. Alasan peneliti memilih teknik sampling ini adalah dikarenakan peneliti bisa lebih leluasa dalam menentukan kriteria partisipan penelitian yang dianggap mengetahui tentang topik penelitian ini tanpa adanya intervensi dari pihak sekolah sehingga informasi yang diperoleh nantinya memang benar-benar valid dan mampu menjawab pertanyaan penelitian dengan apa adanya. Adapun yang menjadi subjek penelitian dalam penelitian ini adalah kepala sekolah, wakil kepala sekolah bidang kurikulum, dan guru-guru yang mewakili setiap jurusan. Sehingga jumlah partisipan adalah sebanyak 7 orang.

\section{Teknik Pengumpulan Data}

Teknik pengumpulan data pada penelitian kualitatif meliputi, observasi, wawancara, dan studi dokumen/dokumentasi. Karena terjadi perubahan pada kebijakan pemerintah yang diakibatkan oleh Pandemi Covid-19, menyebabkan pembelajaran tidak dilakukan lamgsung di sekolah melainkan dilakukan dari rumah secara daring (online). Perubahan kebijakan tersebut mengakibatkan terbatasnya peneliti dalam menghimpun data yang bersifat observasi karena guru di SMK Negeri 1 Kota Jambi tidak hadir setiap hari melainkan datang ke sekolah dengan menggunakan Sistem Shift (pembagian jam kerja), demi tetap menjaga protokol kesehatan. Disamping itu, peneliti juga tidak diberi izin untuk mengakses dokumen yang terkait dengan implementasi supervisi akademik kepala sekolah di SMK Negeri 1 Kota Jambi terutama dokumen terkait perencanaan supervisi akademik. Oleh karenanya, mengingat keterbatasan tersebut, maka dalam penelitian ini teknik pengumpulan data yang peneliti gunakan adalah teknik wawancara. Afrizal (2016) mengemukakan bahwa dalm penelitan kualitatf tekniik wawancara merupakan teknik penghimpun data yang umum atau familiar di gunakan oleh peneliti. 
Adapun jenis wawancara yang digunakan dalam penelitian ini adalah wawancara terstruktur. Sugiyono (2016) mendefinisikan wawancara terstruktur sebagai teknik penghimpun data dimana peneliti sudah mempunyai gambaran terkait informasi yang akan diperoleh. Oleh karenanya, peneliti terlebih dahulu menyiapkan instrumen wawancara atau pedoman wawancara yang berupa daftar pertanyaan yang akan diajukan saat wawancara. Nantinya responden penelitian akan diberikan pertanyaan yang serupa yang kemudian jawaban dari pertanyaan tersebut akan dicatat oleh peneliti. Dan wawancara yang digunakan dalam penelitian ini dilakukan secara terbuka dimana responden penelitian secara sadar mengetahui bahwa sedang diwawancarai serta mengetahui tujuan dan maksud wawancara. Wawancara ini terfokus pada implementasi supervisi akademik kepala sekolah yang ditinjau dari segi aspek supervsi akadmik yang terdiri dari aspek perencanan, aspek pelaksanan, dan aspek tindak lanjut supervsi akadmik. Sedangkan lama dan lokasi wawancara akan disesuaikan dengan kondisi partisipan penelitian.

\section{Teknik Uji Keabsahan Data}

Dalam penelitian ini teknik pemeriksaan keabsahan data yang digunakan adalah teknik Triangulasi. Moleong (2014) mendefinisikan triangulasi sebagai teknik uji keabsahan data dimana peneliti melakukan pengecakan dan melakukan perbandingan terhadap data yang telah diperoleh dengan memanfaatkan sesuatu diluar data tersebut. Denzin (Moleong, 2014) mengklasifikasikan teknik pemeriksaan keabsahan data ini menjadi empat macam yaitu tringulasi dengan sumber, metode, penyidik dan teori. Dalam penelitian ini peneliti menggunakan teknik pemeriksaan keabsahan data triangulasi dengan sumber.

Triangulasi dengan sumber adalah teknik pemeriksaan keabsahan data dengan mengecek dan membandingkan informasi yang telah diperoleh dari masing-masing partisipan melalui waktu dan alat yang berbeda sehingga memperoleh data yang valid (Patton dalam Moleong, 2014). Adapun langkah-langkah yang peneliti lakukan dalam triangulasi data yaitu: 1). Peneliti melakukan triangulasi seminggu setelah melakukan wawancara. 2). Melakukan pencatatan dan dokumentasi di setiap kegiatan secara lengkap. 3). Sesegera mungkin mengolah data penelitian guna menghindari subjektifitas data penelitian. 4). Peneliti berulang kali melakukan pengecekan informasi yang telah diperoleh baik itu berupa rekaman suara, video, trasnkip wawancara ataupun angket penelitian.

\section{Teknik Analisis Data}

Bogdan \& Biklen (Sugiyono, 2014) mengemukakan bahwa analisis data dalam penelitian kualitatif merupakan proses atau tahapan yang dilakukan peneliti setelah melakukan pengambilan data yang dapat berupa hasil wawancara, catatan di lapangan, maupun dokumen kegiatan, dimana data yang telah diperoleh tersebut akan diklasifikasikan ke dalam beberapa kategori, kemudian menjabarkannya ke dalam unit-unit, melakukan sintesa terhadap data tersebut, menyusun data kedalam pola, memilah data yang penting dan akan dipelajari, serta terkahir adalah membuat kesimpulan yang komunikatif.

Dalam penelitian ini, data dianalisis dengan mengacu pada pendapat yang dikemukakan oleh Miles dan Huberman yang dikutip oleh Sugiyono (2014) yang meliputi sebagai berikut: 1). Reduksi Data. Yakni penulis memilah berbagai data yang ada menjadi data dianggap penting dan yang mendukung penelitian ini. Sehingga dari data yang diperoleh tersebut penulis dapat memberi gambaran yang jelas serta mempermudah peneliti melakukan penghimpunan data selanjutnya guna mencapai tujuan penelitian ini yaitu mendeskripsikan implementasi supervisi akademik kepala sekolah di SMK Negeri 1 Kota Jambi. 2). Penyajian Data. Yakni menyajikan data kedalam transkip wawancara yang kemudian data tersebut dinarasikan guna menjabarkan dan mendeskripsikan temuan-temuan terkait implementasi supervisi akademik 
kepala sekolah di SMK Negeri 1 Kota Jambi secara apa adanya. 3). Penarikan Kesimpulan. Yakni menarik kesimpulan dengan berdasarkan data-data yang sudah disajikan dalam tahap sebelumnya.

\section{Prosedur Penelitian}

Prosedur penelitian yang digunakan adalah 1). Tahap pra-lapangan. Yaitu dengan melakukan: a). Mengurus perizinan. b). Menyusun instrumen penelitian. c). Mengatur jadwal. 2). Tahap Pekerjaan Lapangan. Dalam tahap ini, peneliti melakukan wawancara dan dokumentasi bersama partisipan penelitian untuk mengetahui implemntasi supervisi akademiik kepala sekola di SMK Negeri 1 Kota Jambi yang ditinjau dari aspek perencanaan, aspek pelaksanaan, dan aspek tindak lanjut supervisi akademik sehingga data dapat dipercaya dan akurat.

\section{HASIL PENELITIAN}

Berdasarkan hasil wawancara yang dilakukan bersama dengan 7 orang partisipan, diketahui bahwa terdapat beberapa hal penting yang berkaitan dengan Implementasi Supervisi Akademik Kepala Sekolah di SMK Negeri 1 Kota Jambi. Agar mempermudah dalam mendeskripsikan hasil penelitian ini, maka peneliti mengklasifikasikan kedalam tema dan sub tema penelitian yang tentunya berkaitan erat dengan judul penelitian ini sehingga dapat menjawab pertanyaan penelitian. Adapun klasifikasi tema dan sub tema penelitian adalah sebagai berikut:

Tabel 1. Tema dan sub tema penelitian

\begin{tabular}{|c|l|l|}
\hline No & \multicolumn{1}{|c|}{ Tema } & \multicolumn{1}{c|}{ Sub Tema } \\
\hline 1. & $\begin{array}{l}\text { Implementasi Supervisi } \\
\text { Akademik Kepala Sekolah }\end{array}$ & $\begin{array}{l}\text { Perencanaan kegiatan supervisi akademik yang } \\
\text { dalam prosesnya melibatkan seluruh elemen guru } \\
\text { serta menyesuaikan dengan kebutuhan guru. }\end{array}$ \\
\cline { 3 - 4 } & & $\begin{array}{l}\text { Pelaksanaan kegiatan supervisi akademik dengan } \\
\text { turun langsung memantau dan mengamati proses } \\
\text { belajar mengajar yang dilakukan guru. }\end{array}$ \\
\cline { 3 - 4 } & $\begin{array}{l}\text { Tindak lanjut kegiatan supervisi akademik dalam } \\
\text { bentuk pemberian penguatan, dorongan, } \\
\text { pembinaan, arahan, serta bimbingan dan } \\
\text { memberikan solusi terhadap permasalahan yang } \\
\text { dihadapi guru selama mengajar. }\end{array}$ \\
\hline
\end{tabular}

Berdasarkan klasifikasi tema dan sub tema penelitian dalam tabel di atas, maka deskripsi tentang temuan dan hasil penelitian akan dijabarkan dalam penjelasan dibawah ini:

\section{Implementasi Supervisi Akademik Kepala Sekolah di SMK Negeri 1 Kota Jambi}

Kepala sekolah sebagai penanggung jawab penyelenggaraan pendidikan atau pembelajaran di sekolah, memiliki pengaruh yang besar pada peningkatan mutu proses pembelajaran, baik melalui pelaksanaan supervisi yang efektif maupun kebijakan dalam meningkatkan kompetensi para pendidik. Dalam upaya memastikan pembelajaran berjalan efektif dan bermutu, perlu 
dilakukan upaya-upaya membantu guru dalam mengembangkan dan meningkatkan mutu proses pembelajaran. Supervisi akademik oleh kepala sekolah menjadi hal yang sangat penting dalam upaya tersebut.

Berdasarkan hasil wawancara yang dilakukan peneliti bersama dengan kepala sekolah dan guru, upaya yang dilakukan oleh kepala sekolah dalam menjalankan perannya sebagai supervisor akademik di SMK Negeri 1 Kota Jambi yang ditinjau dari aspek perencanaan, pelaksanaan, dan tindak lanjut program supervisi akademik, adalah sebagai berikut:

\section{Implementasi Supervisi Akademik Kepala Sekolah ditinjau dari Aspek Perencanaan Supervisi Akademik}

Berdasarkan hasil wawancara bersama dengan partisipan penelitian, ditemukan bahwa kepala sekolah dalam hal perencanaan program supervisi akademik belum melibatkan seluruh elemen guru melainkan hanya melibatkan Tim Manajemen Sekolah atau Tim Supervisi (Top Management) dan kurang melakukan sosialisasi kepada guru terkait jadwal pelaksanaan supervisi akademik. Adapun penjabaran hasil wawancara sehubungan perencanaan supervisi akademik adalah sebagai berikut:

\section{Perencanaan Program Supervisi Akademik hanya Melibatkan Tim Manajemen Sekolah (Top Management)}

Keberhasilan program supervisi akademik tidak terlepas dari perencanaan program yang dilakukan dengan sebaik-baiknya. Dalam merencanakan program supervisi akademik kepala sekolah harus menyesuaikan dengan kebutuhan guru serta melibatkan guru dalam proses penyusunannya agar tepat sasaran. Di SMK Negeri 1 Kota Jambi, perencanaan program supervisi akademik dilakukan oleh kepala sekolah dengan hanya melibatkan tim manajemen sekolah atau tim supervisi yang terdiri dari wakil kepala sekolah dan beberapa guru senior. Hal ini dibuktikan dengan pernyataan dari partisipan pertama yaitu "Se" yang menyatakan sebagai berikut:

"Iya tentu saja kita libatkan guru, namun tidak semua guru kita libatkan. Kita ada membentuk tim supervisi yang terdiri dari tim manajemen sekolah yaitu terdiri dari para wakil kepala sekolah dan termasuk didalamnya beberapa guru senior." (Wawancara dengan partisipan 1 pada 8 Februari 2021)

Pernyataan yang serupa juga diungkapkan oleh partisipan kedua yaitu "Nn" sebagai berikut:

"Untuk menjadi tim supervisi iya tentu dilibatkan, termasuk dalam hal ini adalah perencanaannya. Sebab kan ini merupakan program, sudah sewajarnya memang terencana." (Wawancara dengan partisipan 2 pada 10 Februari 2021)

Hal tersebut juga diperkuat oleh partisipan ketiga yaitu "Sy", dimana beliau mengemukakan sebagai berikut:

"Biasanya yang dilibatkan itu tim manajemen sekolah kalau guru tidak. Nanti melalui wakil kepala sekolah bidang kurikulum akan menginformasikan bahwa guru akan disupervisi pada tanggal-tanggal yang disepakati." (Wawancara dengan partisipan ketiga pada 15 Februari 2021)

Partisipan kelima yaitu "Hr" juga mengemukakan sebagai berikut:

"Sebagai tim manajemen sekolah iya dilibatkan. Ya ikut membantu terutama dalam menentukan jadwal pelaksanaan supervisi dan sosialisasi kepada guru-gurunya ya" (Wawancara dengan partisipan kelima pada 22 Februari 2021)

Berdasarkan hasil wawancara tersebut, dapat disimpulkan bahwa kepala sekolah dalam merencanakan program supervisi akademik sudah cukup baik namun belum optimal. Hal ini dibuktikan dengan kepala sekolah yang dalam perencanaan supervisi akademik sudah melibatkan guru dalam penyusunannya. Kendati demikian, kepala sekolah tidak melibatkan 
seluruh guru di SMK Negeri 1 Kota Jambi namun kepala sekolah dalam menyusun perencanaan supervisi akademik hanya melibatkan dan dibantu oleh guru yang diwakilkan tim supervisi atau tim manajemen sekolah yang sebelumnya ditunjuk oleh kepala sekolah yang terdiri atas wakil kepala sekolah dan beberapa guru senior.

\section{Kurangnya Sosialisasi Kepada Guru terkait Jadwal Pelaksanaan Supervisi Akademik}

Selain melibatkan guru dalam menyusun perencanaan program supervisi akademik. Kepala sekolah juga membuat perencanaan supervisi akademik dengan menyusun jadwal pelaksanaan supervisi akademik. Penyusunan jadwal ini bertujuan agar supervisi akademik dilakukan secara terjadwal, dan guru yang disupervisi mengetahui bahwa akan segera disupervisi sehingga dapat mempersiapkan diri dengan baik.

Sebagaimana yang diungkapkan oleh partisipan pertama yaitu "Se" sebagai berikut:

"Mulai tahun ajaran baru tepatnya sekitar Februari 2020 program supervisi ini sebetulnya sudah dirancang. Dalam rancangannya sudah dijadwalkan pelaksanaan supervisi akademik yaitu sebanyak 1 kali per 6 bulan. Jadi dalam setahun itu kita melaksanakan supervisi akademik sebanyak 2 kali." (Wawancara dengan partisipan 1 pada 8 Februari 2021).

Hal yang serupa diungkapkan oleh partisipan kelima yaitu "Hr", dimana beliau mengemukakan sebagai berikut:

"Iya dijadwalkan. Guru-guru yang akan di supervisi akan diberitahukan sebelumnya bahwasanya kepala sekolah atau tim manajemen sekolah akan mengadakan kunjungan kelas atau supervisi. Biasanyanya itu tiap semester minimal ada 1 kali kunjungan kelas, maksimalnya itu 2x dalam setahun. Selama daring ini supervisinya tiap hari dilakukan, ya itu tadi ya setelah mengajar kita langsung melaporkan kegiatan mengajar yang telah dilakukan." (Wawancara dengan partisipan kelima pada 22 Februari 2021)

Pernyataan yang serupa juga ditambahkan oleh partisipan kedua yaitu "Nn" sebagai berikut: "Terkadang ya. Kadang kita diberitahukan bahwa akan diadakan supervisi, namun juga kadang tidak diberitahukan. Tergantung lah ya, sebab saya sendiri mendapatkan supervisi itu tidak rutin, tetapi sesekali ada, paling maksimal itu sekitar 2 kali dalam setahun. Namun diluar jadwal itu, kadang-kadang kepala sekolah menyempatkan waktu untuk berdialog atau berdiskusi bersama dengan guru terkait kesulitan yang dihadapi selama mengajar. Tidak sering memang, tapi ada waktu-waktu tertentu misalnya pada jam istirahat atau kadang saat rapat bersama, secara tidak langsung nanti akan diselingi." (Partisipan 2, wawancara pada tanggal 10 Februari 2021)

Partisipan keenam yaitu "Am" mengemukakan pernyataan sebagai berikut:

"Ini kadang-kadang ya. Ya kadang kita diberitahukan kalau pada tanggal sekian misalnya akan diadakan supervisi, kadang juga tidak diberitahukan. Tapi selama daring ini supervisinya tiap hari dilakukan, karena setelah mengajar itu guru akan langsung melaporkan kegiatan mengajarnya seperti apa melalui google form yang disediakan sekolah ataupun melalui aplikasi LMS." (Partisipan 6, wawancara pada 22 Februari 2021)

Berdasarkan hasil wawancara tersebut, penulis dapat menyimpulkan bahwasanya kepala sekolah dalam penyusunan jadwal pelaksanaan supervisi sudah cukup baik namun belum maksimal. Hal ini dapat terlihat dari hasil wawancara yang menunjukkan bahwa kepala sekolah sudah ada menyusun jadwal pelaksanaan supervisi akademik yaitu sebanyak 2 kali dalam setahun. Namun, ternyata dalam penjadwalan supervisi akademik tersebut kepala sekolah belum maksimal, dimana ada sebagian guru yang diberitahukan atau mengetahui jadwal pelaksanaan supervisi akademik, namun ada pula sebagian guru yang tidak mengetahui 
atau tidak diberitahukan perihal jadwal pelaksanaan supervisi akademik. Hal ini berarti bahwa penyusunan jadwal pelaksanaan supervisi akademik belum dilakukan secara menyeluruh dan mendetail. Khusunya dalam hal ini adalah kepala sekolah maupun tim manajemen sekolah sebagai supervisor belum maksimal mengatur jadwal serta mensosialisasikan perihal jadwal pelaksanaan supervisi akademik kepada guru-guru.

\section{Implementasi Supervisi Akademik Kepala Sekolah ditunjau dari Aspek Pelaksanaan Supervisi Akademik}

Berdasarkan hasil wawancara bersama dengan partisipan penelitian terkait dengan pelaksanaan supervisi akademik, diperoleh hasil penelitian sebagai berikut:

\section{Kepala Sekolah Jarang Terlibat Langsung dalam Mensupervisi Guru ke Kelas dan Pelaksanaan Supervisi Akademik Belum Merata}

Dalam pelaksanaan supervisi akademik, kepala sekolah sebagai supervisor akan turun langsung untuk mengamati dan melihat kegiatan selama guru mengajar di kelas, kemudian akan melakukan penilaian dan pencatatan sebagai bahan masukan pada saat evaluasi nanti. Kegiatan pelaksanaan supervisi akademik ini tentunya berpedoman pada perencanaan supervisi akademik yang telah disusun sebelumnya.

Di SMK Negeri 1 Kota Jambi, kepala sekolah jarang terlibat dalam pelaksanaan supervisi akademik secara langsung. Melalui tim supervisi atau tim manajemen sekolah yang telah dibentuk, kepala sekolah akan diwakilkan untuk melakukan supervisi akademik kepada guru-guru yang bersangkutan.

Hal tersebut didukung dengan pernyataan dari partisipan pertama yaitu "Se" sebagai berikut:

"Pertama sekali itu saya menentukan dan menunjuk supervisor yang mewakili atas nama kepala sekolah yang mana biasanya itu adalah guru - guru senior yang dalam hal ini pernah mengikuti pelatihan supervisor dan yang memahami bagaimana menjadi supervisor. Kedua, dibentuklah kelompok kerja atau pokjanya. Selanjutnya itu, kita atur jadwal kapan supervisi ini akan dilakukan, disini kita sekaligus mensosialisasikan bahwa akan dilaksanakan supervisi. Setelah semuanya diatur barulah setelah itu supervisornya bergerak melakukan supervisi kepada guru - guru. Kemudian nanti kepala sekolah yang akan mengevaluasi pekerjaan dari supervisornya untuk diberikan feedback atau tindak lanjutnya." (Wawancara dengan partisipan 1 pada 8 Februari 2021)

Pernyataan yang senada juga dikemukakan oleh partisipan kedua yaitu "Nn" dimana beliau mengemukakan sebagai berikut:

"Disini kita bukan kepala sekolah langsung yang melakukan supervisi, memang ada kepala sekolah melakukan supervisi tapi hanya sekali-kali. Disini kita punya tim supervisi yaitu dari tim manajemen yang didalamnya terdiri dari wakil kepala sekolah dan beberapa guru senior. Tim manajemen ini dibentuk berdasarkan surat tugas kepala sekolah yang menugaskan mereka menjadi supervisor. Saya sendiri mendapatkan supervisi itu tidak rutin, tetapi sesekali ada, paling maksimal itu sekitar 2 kali dalam setahun." (Wawancara dengan partisipan 2 pada tanggal 10 Februari 2021)

Partisipan keempat yaitu "Yn" juga mengemukakan hal yang serupa bahwa:

"Biasanya yang mensupervisi itu tim supervisi atau tim manajemen sekolah. Kalau kepala sekolah jarang ya. Saya sendiri termasuk jarang disupervisi. Apalagi dimasa pandemi ini, memang tidak ada sama sekali kunjungan kelas tapi secara online ya masih ada." (Wawancara dengan partisipan 4 pada tanggal 15 Februari 2021)

Lebih lanjut, Partisipan keempat "Yn" juga menambahkan sebagai berikut:

"Saya kurang tau juga ya dengan guru yang lain itu bagaimana, jadi tidak bisa saya 
pastikan juga karena supervisi guru yang lain dilaksanakan kapan dan bagaimana saya tidak tau karena tidak terjadwal tadi. Untuk di jurusan TKJ sendiri memang gurugurunya sangat jarang disupervisi" (Wawancara dengan partisipan 4 pada tanggal 15 Februari 2021)

Partisipan ketujuh yaitu 'Er' juga mengemukakan hal yang serupa yaitu sebagai berikut:

"Sedang lah ya. Kadang sering, kadang juga jarang. Biasanya supervisi itu dilakukan dalam setahun 2x. Saya juga termasuk jarang gitu, ada tapi ya tidak menentu." (Wawancara dengan partisipan 7 pada 22 Februari 2021)

Berdasarkan hasil wawancara tersebet, penulis bisa menyimpulkan bahwasanya kepala sekolah dalam menjalankan perannya sebagai supervisor akademik belum sepenuhnya optimal. Hal ini terlihat dari pernyataan kepala sekolah sendiri yang menyebutkan bahwa beliau menunjuk tim supervisi yang mewakili kepala sekolah sebagai supervisor untuk terjun langsung mensupervisi para guru, sedangkan kepala sekolah nantinya yang akan mengevaluasi pekerjaan dari tim supervisor yang sudah dibentuk tersebut. Hal tersebut didukung pula dengan pernyataan beberapa guru yang jarang mendapati kepala sekolah turun langsung dalam melakukan supervisi akademik. Melainkan hanya diwakilkan oleh tim manajemen atau tim supervisi saja. Dari pernyataan para guru tersebut, juga dapat diketahui bahwa pelaksanaan supervisi akademik belum dilakukan secara merata. Masih terdapat sebagian guru yang jarang mendapatkan supervisii akadmik.

\section{Pelaksanaan Supervisi Akademik dilakukan secara Daring}

Pelaksanaan supervisi akademik di SMK Negeri 1 Kota Jambi dalam kurun waktu satu tahun terakhir belum sepenuhnya optimal terlaksana. Pandemi yang melanda Indonesia sejak maret 2020 menjadi salah satu penyebabnya. Dimana terjadi berbagai perubahan pada kebijakan pemerintah, salah satunya adalah kebijakan yang mengharuskan satuan pendidikan untuk meniadakan pembelajaran tatap muka dan menggantikannya dengan pembelajaran secara daring sehingga hal ini menyebabkan program supervisi akademik tidak berjalan optimal. Hal ini diakui oleh partisipan pertama yaitu "Se" yang menyatakan pendapatnya sebagai berikut:

"Mulai tahun ajaran baru tepatnya sekitar Februari 2020 program supervisi ini sebetulnya sudah dirancang. Dalam rancangannya sudah dijadwalkan pelaksanaan supervisi akademik yaitu sebanyak 1 kali per 6 bulan. Jadi dalam setahun itu kita melaksanakan supervisi akademik sebanyak 2 kali. Namun terhitung pada bulan Maret 2020 terjadi perubahan pada tatanan kebijakan yang menyebabkan pembelajaran dilakukan dari rumah (online). Adanya perubahan tatanan kebijakan ini menyebabkan pelaksanaan supervisi akademik belum maksimal atau optimal saya laksanakan. Bukan berarti tidak terlaksana sepenuhnya, hanya saja fokusnya atau sifatnya itu lebih kepada ada tidaknya guru memberikan materi ajar dan siswa mengikuti pembelajaran sebab kegiatan belajar mengajar dilakukan secara daring. Nah untuk ini sendiri kita rutin melakukan pengecekan kehadiran guru apa memang betul mengajar atau tidak dan materi yang diajarkan itu apa." (Wawancara dengan partisipan 1 pada 8 Februari 2021)

Hal yang sama turut diungkapkan partisipan ketiga yaitu "Sy" pada wawancara yang dilakukan pada 15 Februari 2021, dimana beliau mengungkapkan sebagai berikut:

"Hanya saja sejak Maret 2020 sampai sekarang belum ada kegiatan supervisi. Karena pandemi ini, kita belajarnya dari rumah. Setau saya menurut kepala sekolah sendiri, beliau sudah ada membuat program supervisi namun masih program lama atau yang biasa yang belum disesuaikan dengan kebijakan di masa pandemi. Untuk selama pandemi ini belum ada petunjuknya jadi belum bisa melakukan supervisi akademik karena metodenya baru yaitu daring. Jadi ragu juga mau melakukan supervisi atau kunjungan kelas takut melanggar protokol kesehatan." 
Partisipan Kelima yaitu “Hr" juga mengemukakan pendapat yang serupa yaitu sebagai berikut: "Kita disini sekarang online ya supervisinya. Karena belajar dari rumah, jadi mau tidak mau supervisinya dilakukan dari rumah juga (online). Memang untuk kunjungan ke kelas-kelas itu belum ada ya selama daring ini, tapi RPP yang dibuat guru itu tetap dikumpulkan dan kegiatan belajar mengajar juga setiap harinya dilaporkan baik lewat laporan harian ataupun langsung dari LMS. Selama daring ini bisa dibilang supervisinya lebih ke arah administrasinya saja ya dan mungkin juga lebih kepada kehadiran daripada guru-guru memang betul melaksanakan tugasnya atau tidak, begitu." (Partisipan kelima, wawancara pada 22 Februari 2021)

Berdasarkan hasil wawancara tersebut, diketahui bahwa pelaksanaan supervisi akademik di SMK Negeri 1 Kota jambi khususnya pada kurun waktu satu tahun terakhir belum maksimal dilaksanakan. Hal ini dikarenakan terjadinya perubahan pada tatanan kebijakan yang menyebabkan pembelajaran dilakukan secara daring. Sehingga tidak adanya kegiatan supervisi akademik khusunya dalam hal kunjungan kelas. Kendati demiakian, berdasarkan pernyataan yang diungkapkan oleh partisipan satu, tiga, dan lima dapat diketahui pula bahwa supervisi akademik di SMK Negeri 1 Kota jambi masih diupayakan untuk dilaksanakan walaupun dilakukan secara daring dengan fokusnya yang lebih cenderung pada administrasinya saja dan mengawasi kehadiran guru, yang dalam hal ini dilihat dari kehadiran guru saat mengajar online, memang benar guru mengajar atau tidak, dan ada tidaknya guru memberikan materi ajar kepada peserta didik.

Pada umumnya kepala sekolah dalam melaksanakan supervisi akademik menggunakan teknik kunjungan kelas, obsevasi kelas, maupun pertemuan individual. Namun, dalam kurun waktu satu tahun terakhir kepala sekolah melakukan pengawasan atau supervisi secara daring dengan dibantu sistem e-learning yang digunakan SMK Negeri 1 Kota Jambi sebagai media belajar online yaitu LMS (Learning Management System) dan laporan harian yang dikirimkan oleh masing-masing guru. Sebagaimana yang diungkapkan oleh partisipan pertama yaitu "Se" sebagai berikut:

"Umumnya kita melakukan kunjungan kelas atau observasi kelas ataupun dengan memanggil langsung gurunya untuk menghadap. Adapun untuk caranya yaitu kita atur jadwal supervisinya, selepas itu meminta guru yang bersangkutan menyiapkan perangkat mengajar, kemudian barulah kita melakukan kunjungan kelas. Namun satu tahun terakhir bisa dibilang kunjungan kelas itu tidak ada karena daring. Tapi tetap guru diminta membuat laporan belajar mengajar, jadi tidak semata-mata guru bisa santai ataupun lalai dalam mengajar karena ada laporan pertanggungjawabannya. Disamping itu, SMKN 1 punya sistem e-learning sendiri yang mana sistem ini dapat memantau apakah guru melaksanakan tugas mengajarnya atau tidak. Sistem itu sendiri namanya LMS (Learning Management System) yang merupakan aplikasi daring untuk proses belajar mengajar dimana didalamnya kepala sekolah melalui operator sekolah mempunyai akses untuk memantau kehadiran guru, materi ajar yang diajarkan, bahkan kehadiran siswa sendiri." (Partispan 1, 8 Februari 2021)

Partisipan ketiga yaitu "Sy" mengemukakan pendapatnya sebagai berikut:

"Umumnya sih melakukan kunjungan kelas. Selama daring ini mungkin supervisinya bisa dibilang online melalui LMS dan laporan yang dikirim per guru." (Partisipan 3, pada tanggal 15 Februari 2021)

Menurut partisipan Keenam yaitu "Am" teknik supervisi yang digunakan dalam supervisi akademik adalah sebagai berikut:

"Normalnya kunjungan kelas atau kadang-kadang ada pemanggilan guru secara individu. Tapi karena sudah daring sejak dua semester lalu, supervisinya juga disesuaikan dengan daring pula. Lebih ke administrasinya sih, kita seperti mengirim 
laporan mengajar tiap hari, mengumpulkan RPP, melaporkan siswa yang tidak ikut daring, seperti itu sih." (Partisipan 6, wawancara pada 22 Februari 2021)

Partisipan Ketujuh yaitu "Er" juga mengemukakan pendapat yang serupa yaitu sebagai berikut:

"Seringnya kunjungan kelas atau selama pandemi ini ya dari LMS Kepala sekolah atau yang biasa diwakili oleh tim manajemen sekolah biasanya melakukan kunjungan ke kelas-kelas melihat proses belajar mengajar. Tapi sudah sekitar setahun ini tidak ada kunjungan kelas digantikan dengan laporan secara online ke kepala sekolah atau tim yang mewakili." (Partisipan 7, wawancara pada 22 Februari 2021)

Berdasarkan pemaparan hasil wawancara di atas, dapat peneliti simpulkan bahwasanya pelaksanaan supervisi akademik pada dasarnya cukup baik meskipun belum optimal. Terlihat dari hasil wawancara yang menyatakan bahwa (1) Kepala sekolah jarang terjun langsung dalam mensupervisi melainkan diwakilkan oleh tim manajemen sekolah atau tim supervisi dan Pelaksanaan supervisi akademik belum dilakukan secara merata dimana masih terdapat sebagian guru yang jarang disupervisi; (2) Pelaksanaan kegiatan supervisi akademik yang terhambat dikarenakan pandemi Covid-19 sehingga pelaksanaan supervisi akademik dilakukan secara daring dengan fokus pada administrasi mengajar guru serta kehadiran guru saat mengajar. Berdasarkan hal-hal tersebut, menunjukkan bahwa supervisi akademik yang dilakukan oleh kepala sekolah belum efektif dan perlu upaya-upaya perbaikan agar sasaran dan tujuan supervisi akademik ini sendiri dapat terwujud sehingga menciptakan dan meningkatkan kualitas pembelajaran.

\section{Implementasi Supervisi Akademik Kepala Sekolah ditinjau dari Aspek Tindak Lanjut Supervisi Akademik}

Tindak lanjut atau evaluasi supervisi akademik merupakan kegiatan dalam rangka pemberian umpan balik (feedback) terhadap hasil pengamatan dan penilaian yang dilakukan kepala sekolah pada saat mengamati dan mengikuti kegiatan guru selama mengajar yang di dalam kelas. Di SMK Negeri 1 Kota Jambi, kepala sekolah turut berpartisipasi aktif dalam kegiatan evaluasi atau tindak lanjut supervisi akademik ini. Sebagai pemegang kekuasaan tertinggi, kepala sekolah memiliki wewenang dalam menetapkan keputusan-keputusan yang dalam hal ini adalah menentukan tindak lanjut yang tepat terhadap persoalan yang ditemui saat supervisi berlangsung. Adapun bentuk tindak lanjut supervisi akademik yang dilakukan kepala sekolah dapat berupa pemberian dorongan, penguatan, arahan dan bimbingan, pembinaan, hingga pemberian solusi terhadap permasalahan dihadapi guru selama mengajar di kelas.

Hal ini sesuai dengan yang diungkapkan oleh partisipan pertama yaitu "Se" bahwasanya adalah sebagai berikut:

"Pada umumnya guru yang bersangkutan itu kita ajak diskusi akhir, kita panggil untuk menghadap. Disini akan kita ajak beliau ngobrol seputar permasalahannya apa kesulitannya dimana selepas itu kita carikan solusinya kemudian beliau kita tuntun dan kita bina. Seperti itu sih pada umumnya." (wawancara dengan partisipan 1, pada tanggal 8 Februari 2021)

Hal yang senada turut diungkapkan oleh partisipan kedua yaitu "Nn" yang menyatakan bahwa: "Yang selama ini, akan ada pembinaan langsung baik itu dari kepala sekolah sendiri maupun dari tim supervisi atau tim manajemen sekolah. Seperti misalnya berupa arahan dari guru senior, motivasi, dan lain sebagainya." (Partisipan 2, wawancara 10 Februari 2021)

Selanjutnya, partisipan kelima yaitu "Hr" juga menyatakan bahwa:

"Tindak lanjut ini bentuknya tidak jauh dari pembinaan atau pemberian motivasi dan masukan ya. Nanti biasanya setelah kunjungan kelas, kepala sekolah akan memanggil guru untuk menghadap. Nanti guru-guru akan ditanyai mengenai kelengkapan 
mengajarnya, kesulitannya apa, kemudian juga kepala sekolah akan menyampaikan guru ini lebihnya dimana dan guru ini kurangnya dimana, nanti juga akan diberi masukan, saran juga solusi. Tidak bosan juga kepala sekolah mengingatkan kita untuk terus meningkatkan kompetensi." (Partisipan 5, wawancara pada 22 Februari 2021)

Partisipan keenam yaitu "Am" juga turut mengemukakan pendapatnya bahwa:

"Biasanya dilakukan pembinaan ya, termasuk didalamnya guru diarahkan, diberitahukan kekurangannya dimana, apa yang harus diperbaiki, diberi solusi juga. Kalau memang dirasa genting dan sangat perlu diberikan pelatihan biasanya akan jadi prioritas untuk dikirim mengikuti diklat." (Partsipan keenam, wawancara pada 22 Februari 2021)

Berdasarkan hasil wawancara di atas, dapat disimpulkan bahwa kepala sekolah dalam melaksanakan tindak lanjut supervisi akademik sudah baik. Hal ini dapat terlihat dari kepala sekola yang terlibat langsung dalam kegiatan evaluasi dengan memberikan masukan-masukan dan saran serta memberi solusi terhadap kesulitan yang dihadapi guru selama mengajar.

Sebagai pemimpin tertinggi dalam organisasi sekolah, kepala sekolah tentu sering memberikan dorongan ataupun motivasi kepada staffnya, khususnya guru. Hal ini dilakukan agar guru menjadi semangat dan termotivasi untuk terus meningkatkan kinerja dan kemampuan mengajarnya. Pemberian motivasi ini selain sebagai bentuk supervisi juga sebagai bentuk apresiasi dari kepala sekolah terhadap kinerja guru. Sebagaimana yang dikemukakan oleh partisipan 1 yaitu "Se" sebagai berikut:

"Dengan adanya perubahan pada tatanan baru ini motivasi yang paling sederhana adalah bagaimana saya memberikan semacam dorongan dan semangat agar guru mampu menyesuaikan diri dengan perkembangan teknologi sebab sekarang ini sudah zamannya serba online atau daring. Jadi guru itu perlu di support untuk terus belajar dan berkembang." (Wawancara dengan partisipan pertama pada 8 Februari 2021)

Partisipan ketiga "Sy" juga mengemukakan pendapat yang senada tentang pemberian motivasi oleh kepala sekolah, berikut penyataannya:

"Karena ada laporan daring tiap harinya dan dari aplikasi e-learning kita yaitu LMS akan tampak siapa guru yang mengajar atau tidak. Kepala sekolah jadi sering mengingatkan dan memotivasi kita untuk semangat mengajarnya, dan meminta kita untuk terus memantau anak didik agar selalu mengikuti pelajaran. Waktu rapat bersama guru pun kepala sekolah tidak lupa untuk mengingatkan kita." (Partisipan 3, Wawancara pada 15 Februari 2021)

Dalam pemberian pembinaan pun, kepala sekolah aktif dalam mengikutsertakan guru dalam berbagai macam kegiatan pelatihan atau workshop dalam rangka untuk meningkatkan keterampilan atau kemampuan guru. Hal ini cukup rutin kepala sekolah lakukan dengan melibatkan guru baik dalam pelatihan/workshop yang dilakukan internal maupun eksternal. Partisipan pertama yaitu "Se" mengemukakan sebagai berikut:

"Memberikan pembinaan ini sebenarnya banyak cara ya, seperti yang disebutkan diawal tadi guru itu kita ajak diskusi, kita ajak ngobrol terkait kesulitan yang dihadapi kemudian kita cari solusinya bersama, diiluar jadwal supervisi pun misalnya seperti pada rapat akhir semester kesempatan itu kadang saya gunakan untuk mengevalusi sekilas tentang proses belajar mengajar guru atau bahkan juga guru kita ikutsertakan dalam berbagai macam pelatihan atau workshop guna untuk meningkatkan kompetensinya. Intinya banyak ya yang dapat dilakukan. Namun, tidak hanya sampai sebatas itu saja, tapi perlu juga memasukan unsur lain misalnya melakukan pendekatan khusus seperti menunjukkan simpati atau sentuh mereka dengan perhatian, itu seninya. Jadi tidak semata-mata kita mengemukakan buruknya/kurangnya guru itu saja melainkan ada pendekatan khusus." (Partisipan 1, Wawancara pada 8 Februari 2021) 
Partisipan kedua yaitu "Nn" juga mengemukakan sebagai berikut:

"Workshop ini tiap tahun ada. Biasanya Workshop dalam rangka menyusun perangkat mengajar. Untuk kegiatan pelatihan kalau seandainya ada pihak eksternal yang memang mengundang guru yang bersangkutan tentu diikutsertakan." (Partisipan 2, Wawancara pada 10 Februari 2021)

Selanjutnya, partisipan Ketujuh yaitu "Er" juga menambahkan pendapat yang serupa yakni sebagai berikut:

"Ada, biasanya bergilir. Ya internal ada. Eksternal juga ada. Seperti biasanya awal tahun ada wokshop untuk menyusun RPP, awal corona kemarin juga ada workshop IHT. Itu sekolah yang mengadakan dan mengikutsertakan semua guru. Kalau dari eksternal itu biasanya undangan diklat dari dinas-dinas. Kalau ada biasanya nanti akan ada guru dikirim.” (Partisipan ketujuh, wawancara pada 22 Februari 2021)

Berdasarkan pemaparan hasil wawancara di atas, kesimpulan yang dapat peneliti tarik adalah bahwa kepala sekolah dalam melakukan evaluasi atau tindak lanjut sudah cukup baik. Hal ini dapat dilihat dari kepala sekolah yang memberikan penguatan atau motivasi serta melakukan pembinaan dalam bentuk mengikutsertakan guru-guru dalam kegiatan workshop ataupun pelatihan guna untuk meningkatkan kemampuan profesionalnya.

\section{PEMBAHASAN}

Berdasarkan temuan dan hasil penelitian yang dilakukan bersama dengan 7 orang partisipan yang ada di SMK Negeri 1 Kota Jambi terkait dengan Implementasi Supervisi Akademik Kepala Sekolah yang ditinjau dari aspek perencanaan, aspek pelaksanaan, dan aspek tindak lanjut supervisi akademik, maka dapat dipaparkan hal-hal sebagai berikut:

\section{Implementasi Supervisi Akademik Kepala Sekolah ditinjau dari Aspek Perencanaan Supervisi Akademik}

Berdasarkan hasil wawancara terkait dengan implementasi supervisi akademik kepala sekolah yang dilihat dari aspek perencanaan supervisi akademik, peneliti menemukan bahwa dalam proses perencanaan program supervisi akademik, kepala sekolah sudah membuat perencanaan dengan cukup baik meskipun belum optimal. Hal ini diketahui dari kepala sekolah yang telah membuat perencanaan program supervisi akademik ini pada awal tahun ajaran baru. Selain itu, ternyata dalam proses perencanaan program supervisi akademik kepala sekolah belum melibatkan seluruh guru di SMK Negeri 1 Kota Jambi. Melainkan kepala sekolah hanya melibatkan tim manajemen sekolah atau tim supervisi akademik yang terdiri dari para wakil kepala sekolah dan beberapa guru senior.

Marsono (2016) dalam penelitiannya mengemukakan bahwa dalam perencanaan kegiatan supervisi untuk dapat mengikutsertakan guru, agar mereka mengetahui apa yang harus dipersiapkan dan apa yang harus dikerjakan. Sehingga kegiatan supervisi menjadi lebih terarah dan bisa berjalan dengan lancar. Hal ini sejalan dengan manfaat dari program supervisi akademik yaitu sebagai pedoman pelaksanaan dan pengawasan akademik, untuk menyamakan persepsi seluruh warga sekolah tentang program supervisi akademik. Hal yang senada juga dikemukakan oleh Anissyahmai, Rohiat, dan Juarsa (2017) bahwa keterlibatan guru dan kepala sekolah dalam penyusunan rencana kerja pengawas sangat efektif dalam meningkatkan kompetensi profesional guru dan kemampuan manajerial kepala sekolah. Untuk itu perlu disusun program supervisi yang melibatkan semua komponen.

Masaong (2012) juga menyebutkan bahwa salah satu prinsip dalam supervisi adalah prinsip demokratis, dimana prinsip ini berarti menjunjung tinggi atas musyawarah. Maksudnya adalah kepala sekolah memberikan kesempatan kepada guru untuk mengemukakan pandangan 
dan pendapatnya yang kemudian dijadikan pertimbangan dalam mengambil keputusan. Kemendikbud (2018) juga menyatakan bahwa perumusan tujuan dilakukan secara musyawarah mufakat untuk menyatukan pendapat dalam merumuskan tujuan dengan mempertimbangkan permasalahan guru yang disupervisi sehingga terwujud komitmen bersama.

Selanjutnya, hasil penelitian dari Parida, dkk (2020) menyebutkan bahwa supervisi akademik yang dilakukan kepala sekolah dirancang dengan cara kekeluargaan dan bukan paksaan. Kepala sekolah melakukan rapat sebelum melaksanakan supervisi dan kepala sekolah mempersilahkan guru untuk memberikan masukan agar kegiatan supervisi dapat berjalan dengan baik. Hal ini membuat guru tidak merasa terbebani dengan adanya kegiatan supervisi akademik tersebut.

Merujuk pada hal diatas, dapat dicermati bahwa kepala sekolah dalam merencanakan program supervisi akademik seharusnya melibatkan guru yang akan disupervisi atau dalam hal ini melibatkan secara langsung guru yang bersangkutan. Hal ini dilakukan guna untuk menyamakan persepsi sehingga tujuan ataupun sasaran dari kegiatan supervisi akademik ini menjadi tepat sasaran karena disesuaikan dengan kebutuhan dan kesepakatan bersama dengan guru yang bersangkutan. Namun pada kenyataannya, kepala sekolah belum melibatkan guru yang bersangkutan (yang akan disupervisi) secara langsung melainkan hanya diwakili oleh tim manajemen sekolah atau tim supervisi sekolah.

Selanjutnya, dalam penyusunan perencanaan supervisi akademik, kepala sekolah sudah membuat jadwal pelaksanaan supervisi akademik namun belum maksimal. Kepala sekolah sudah menjadwalkan pelaksanaan supervisi akademik yaitu 1x pelaksanaan per enam bulan, yang artinya dalam setahun akan ada sebanyak $2 x$ pelaksanaan supervisi akademik. Namun meski sudah dijadwalkan, masih terdapat sebagian guru yang tidak diberitahukan terkait jadwal pelaksanaan supervisi akademik tersebut sehingga guru tidak sempat mempersiapkan diri. Hal ini didukung dengan pernyataan Anissyahmai, Rohiat, dan Juarsa (2017) yang dalam hasil penelitiannya mengemukakan bahwa supervisi perlu disusun oleh kepala sekolah dan disosialisasikan kepada guru melalui rapat sekolah, sehingga guru-guru mengetahui dan memahami maksud dan tujuan dari program supervisi itu. Kemendikbud (2018) mengemukakan bahwa kegiatan supervisi dilakukan sesuai jadwal yang telah ditetapkan. Supervisi akademik ini perlu dilakukan sesuai jadwal karena telah disepakati dengan guru yang akan disupervisi. Dengan melaksanakan supervisi secara disiplin, guru akan termotivasi untuk memperbaiki proses pembelajarannya secara berkelanjutan. Tetapi pada prakteknya, guru masih jarang diberitahukan perihal jadwal pelaksanaan supervisi akademik tersebut.

\section{Implementasi Supervisi Akademik Kepala Sekolah ditinjau dari Aspek Pelaksanaan Supervisi Akademik}

Berdasarkan hasil wawancara terkait dengan implementasi supervisi akademik kepala sekolah yang ditinjau dari aspek pelaksanaan supervisi akademik, peneliti menemukan bahwa pelaksanaan supervisi akademik di SMK Negeri 1 Kota Jambi cukup baik namun masih belum optimal. Hal ini diketahui dari kepala sekolah yang jarang turun langsung melakukan supervisi akademik yang dalam hal ini adalah kunjungan kelas. Kepala sekolah hanya diwakilkan oleh tim manajemen sekolah atau tim supervisi untuk turun langsung mensupervisi guru di kelas. Nawawi (Masaong, 2012) mengungkapkan bahwa supervisi akademik merupakan pelayanan yang disediakan oleh pemimpin untuk membantu guru-guru agar menjadi guru atau personal yang semakin cakap sesuai dengan perkembangan ilmu pengetahuan umumnya dan ilmu pendidikan khususnya agar mampu meningkatkan efektifitas proses belajar mengajar di sekolah.

Hal ini sejalan dengan pendapat Mulyasa (2004) yaitu untuk mengetahui sejauh mana guru mampu melaksanakan pembelajaran, secara berkala kepala sekolah perlu melaksanakan 
kegiatan supervisi, yang dapat dilakukan melalui kegiatan kunjungan kelas untuk mengamati proses pembelajaran secara langsung, terutama dalam pemilihan dan penggunaan metode, media yang digunakan dan keterlibatan siswa dalam proses pembelajaran. Suharsaputra (2018) juga mengemukakan bahwa supervisi merupakan bantuan yang diberikan pada guru guna meningkatkan mutu proses pembelajaran dan memperbaikinya, sesuai dengan hasil observasi yang dilakukan oleh kepala sekolah pada kegiatan atau proses pembelajaran yang dilaksanakan oleh guru di dalam kelas.

Selanjutnya, sebagaimana kita ketahui bahwa supervisi merupakan salah satu tugas atau kompetensi yang harus dimiliki kepala sekolah, bukan oleh guru hal ini sesuai dengan Permendiknas Nomor 13 Tahun 2007 tentang standar Kepala Sekolah/Madrasah yang menyebutkan kompetensi yang harus dimiliki kepala sekolah ialah kompetensi kepribadian, kompetensi manajerial, kompetensi kewirausahaan, kompetensi supervisi dan kompetensi sosial. Berdasarkan pendapat para ahli tersebut sudah sewajarnya sebagai pemimpin sekolah, kepala sekolah ikut turun langsung dan terlibat langsung dalam melakukan supervisi kepada guru-guru. Mengingat supervisi merupakan salah satu tugas dari kepala sekolah.

Pelaksanaan supervisi akademik di SMK Negeri 1 Kota Jambi juga masih belum merata, hal ini terlihat dari masih terdapatnya sebagian guru yang jarang atau bahkan tidak disupervisi. Pelaksanaan supervisi yang belum merata tentu akan menyebabkan pada tidak tercapainya tujuan dari pendidikan dalam memperbaiki kualitas pembelajaran. Sebagaimana yang dikemukakan oleh Depdiknas (2004) bahwasanya supervisi sebagai pembinaan dan pengawasan yang yang diberikan kepada seluruh guru disekolah agar mereka dapat meningkatkan kemampuan untuk mengembangkan situasi mengajar dan belajar yang lebih baik di sekolah maupun luar sekolah. Guru sebagai ujung tombak pendidikan perlu diberdayakan serta dibantu untuk mengembangkan kompetensinya guna untuk mewujudkan pendidikan dan pembelajaeran yang berkualitas, salah satunya melalui supervisi oleh kepala sekolah. Sebagaimana yang dikemukakan oleh Sergiovani (Marhawati, 2020) bahwa supervisi akademik dilakukan dengan tujuan untuk membantu guru mengembangkan kemampuan profesionalnya dalam memahami akademik, kehidupan kelas, dan mengembangkan keterampilan mengajarnya.

Pelaksanaan supervisi akademik kepala sekolah di SMK Negeri 1 Kota Jambi terhambat akibat pandemi Covid-19 sehingga menyebabkan tidak adanya kunjungan kelas dan supervisi hanya dilakukan secara daring dengan fokus pada administrasi dan kehadiran guru saja. Merujuk pada hal tersebut, peneliti menilai dan meyakini bahwa pandemi Covid-19 memberi sumbangsih yang cukup besar terhadap pelaksanaan supervisi akademik yang belum optimal di SMK Negeri 1 Kota Jambi disamping faktor lain. Pelaksanaan supervisi akademik di SMK Negeri 1 Kota Jambi khususnya pada masa pandemi tetap diupayakan untuk dilakukan walaupun terbatas dan dilakukan secara online.

Ditinjau dari segi teknik supervisi, diketahui bahwa teknik supervisi bukan hanya kunjungan kelas saja. Sebagaimana yang diungkapkan oleh Suharsaputra (2018) bahwasanya teknik supervisi pendidikan dikelompokkan menjadi dua yaitu teknik yang bersifat kelompok (curah gagasan, fokus grup diskusi, lokakarya, seminar, mentoring, dan lesson study) dan juga teknik yang bersifat individual (kunjungan kelas, observasi kelas, pertemuan individual, kunjungan antarkelas, dan menilai diri sendiri). Jadi meski dilakukan secara online, kepala sekolah diharapkan untuk dapat mensiasati dan mencari alternatif teknik supervisi lain yang dapat digunakan selama pembelajaran berlangsung secara online. Oleh sebab itu, kepala sekolah harus menguasi tidak hanya satu teknik supervisi saja melainkan juga mampu menguasai teknik supervisi lainnya. 


\section{Implementasi Supervisi Akademik Kepala Sekolah ditinjau dari Aspek Tindak Lanjut Supervisi Akademik}

Berdasarkan hasil wawancara terkait dengan implementasi supervisi akademik kepala sekolah yang ditinjau dari aspek tindak lanjut supervisi akademik, peneliti menemukan bahwa kepala sekolah sudah cukup baik dalam memberikan evaluasi ataupun tidak lanjut terhadap pelaksanaan supervisi akademik. Hal ini dibuktikan dengan adanya upaya kepala sekolah dalam memberikan motivasi, arahan, penguatan, saran/solusi maupun pembinaan kepada guru melalui diskusi akhir pasca dilakukannya kunjungan kelas.

Bentuk tindak lanjut lain yang dilakukan kepala sekolah adalah dengan mengajak guru berdiskusi dan mengobrol perihal permasalahan yang dihadapi guru di kelas, kesulitannya apa dan dimana, kemudian guru-guru tersebut akan diberikan masukan dan juga dicarikan solusi terbaik atas permasalahan yang dihadapi. Kemudian guru-guru juga akan diberikan pembinaan berupa pelatihan ataupun workshop guna membantu guru meningkatkan kemampuannya. Hal ini sejalan dengan pendapat Arikunto (2009) dalam Rosidi (2014) yang mengemukakan bahwa tindak lanjut supervisi akademik merupakan tahapan dimana hasil pengamatan yang didapat pada saat dilakukannya kunjungan kelas didiskusikan secara terbuka antara kepala sekolah dan guru.

Disamping itu, bentuk pemberian motivasi yang dilakukan kepala sekolah adalah dengan tidak pernah bosan memberikan semangat dan dorongan kepada guru untuk senantiasa meningkatkan kemampuannya terutama pada masa pandemi ini untuk lebih menyesuaikan diri dengan perkembangan teknologi. Dalam melakukan pembinaan terutama dalam hal pemberian workshop, kepala sekolah rutin mengadakan workshop penyusunan RPP disetiap awal tahun ajaran baru serta mengadakan workshop yaitu IHT (In House Trainning) dalam rangka membantu guru mengoperasikan media belajar online. Selain itu kepala sekolah akan mengikutsertakan guru dalam berbagai pelatihan apabila memang mendapatkan undangan dari pihak luar terutama dari dinas. Pemberian pembinaan berupa workshop dan pelatihan ini adalah guna untuk meningkatkan keterampilan guru. Hal ini sesuai dengan pendapat yang dikemukakan oleh Muspawi, Setiyadi, \& Gunawan (2020) bahwa hal yang dapat dilakukan kepala sekolah dalam rangka membantu meningkatkan kompetensi profesional guru adalah dengan melakukan pembinaan maupun turut melibatkan guru dalam berbagai kegiatan pendidikan seperti pelatihan, seminar, workshop, maupun kelompok kerja guru.

\section{KESIMPULAN}

Berdasarkan hasil penelitian, dapat disimpulkan bahwa impelementasi supervisi akademik kepala sekolah di SMK Negeri 1 Kota Jambi sudah cukup baik namun belum optimal. Hal ini ditinjau dari tiga aspek supervisi akademik yaitu aspek perencanaan, aspek pelaksanaan, dan aspek tindak lanjut sebagai berikut:

a. Ditinjau dari aspek perencanaan supervisi akademik, kepala sekolah belum optimal melibatkan seluruh elemen guru dalam perencanaan program supervisi akademik, sehingga guru kurang mengetahui tujuan, sasaran, metode, pendekatan, dan tindak lanjut seperti apa yang akan diberikan dan ingin dicapai.

b. Ditinjau dari aspek pelaksanaan supervisi akademik, kepala sekolah jarang terjun langsung dalam mensupervisi ke kelas-kelas, biasanya beliau diwakilkan oleh tim supervisi atau tim manajemen sekolah untuk turun mensupervisi guru-guru di kelas. Pelaksanaan supervisi akademik di SMK Negeri 1 Kota Jambi juga belum dilakukan secara merata dimana hal ini dibuktikan dari adanya sebagian guru yang jarang mendapat supervisi. Disamping itu, pelaksanaan supervisi akademik di SMK Negeri 1 Kota Jambi khususnya dalam kurun waktu satu tahun terakhir terhitung sejak 
pandemi Covid-19 dilakukan secara daring dengan fokus pada administrasi dan kehadiran guru saja.

c. Ditinjau dari aspek tindak lanjut supervisi akademik, kepala sekolah telah memberikan tindak lanjut yang cukup baik terhadap hasil supervisi. Hal ini dapat dibuktikan dengan kepala sekolah yang telah melakukan diskusi akhir dengan mengajak guru berdiskusi terkait permasalahan yang dihadapi ketika mengajar, kesulitan apa yang dialami, serta memberikan saran dan solusi terhadap permasalahan tersebut. Selain itu, kepala sekolah turut memberikan pembinaan dengan mengikutsertakan guru-guru dalam berbagai kegiatan workshop dan pelatihan baik yang dilakukan secara internal maupun secara eksternal. Kepala sekolah juga turut memberikan penguatan dan motivasi kepada guru-guru agar

\section{Saran} senantiasa meningkatkan keterampilannya.

Berdasarkan simpulan di atas, berikut saran-saran yang dapat peneliti berikan:

1. Kepala sekolah dalam merencanakan program supervisi akademik sebaiknya melibatkan seluruh elemen guru yang ada di SMK Negeri 1 Kota Jambi hal ini dimaksudkan agar dalam memformulasikan program supervisi akademik kepala sekolah mempertimbangkan saran dan masukan serta harapan guru agar tujuan dan sasaran yang ingin dicapai sesuai dengan kondisi nyata sekolah dan kondisi guru sehingga tujuan dari supervisi akademik tercapai secara optimal.

2. Kepala sekolah hendaknya lebih optimal lagi dalam mengatur jadwal supervisi akademik agar semua guru dapat disupervisi secara merata sehingga tidak ada lagi guru yang jarang atau tidak mendapatkan supervisi.

3. Kepala sekolah hendaknya memahami dan menguasai teknik-teknik supervisi akademik secara mendalam, hal ini dimaksudkan agar jika terjadi gangguan atau hambatan di kemudian hari, kepala sekolah bisa menyesuaikan diri dengan teknik supervisi lain yang lebih sesuai dengan kondisi serta dapat mencari alternatif solusi. Jadi, kepala sekolah tidak hanya terpaku pada satu teknik supervisi saja.

4. Bagi guru, khususnya guru-guru yang jarang mendapatkan supervisi. Hendaknya dapat lebih berinisiatif untuk meminta supervisi kepada kepala sekolah melalui supervisi klinis (supervisi atas inisiatif guru).

\section{DAFTAR PUSTAKA}

Afrizal. (2016). Metode Penelitian Kualitatif. Jakarta: Rajawali.

Anissyahmai, Rohiat, dan Juarsa. (2017). Supervisi Akademik Kepala Sekolah. Jurnal Manajer Pendidikan, 11(2), 89-96.

Arikunto, S. (2004). Dasar - Dasar Supervisi. Jakarta: Rineka Cipta.

Creswell, J. W. (2013). Research Design Pendekatan Kualitatif, Kuantitatif dan Mixed. Yogyakarta: Pustaka Pelajar.

Depdiknas. (2004). Supervisi Akademik Pengawas Sekolah/Madrasah. Jakarta: Direktorat Jenderal PMPTK.

Kemendikbud. (2018). Modul Pengembangan Fungsi Supervisi Akademik dalam Implementasi Kurikulum 2013 jenjang SMK. Jakarta: Direktorat Jendral GTK.

Marhawati, B. (2020). Pelaksanaan Supervisi Akademik Kepala Sekolah Dasar: Studi Kualitatif. JMSP (Jurnal Manajemen dan Supervisi Pendidikan), 4(2).

Marsono. (2016). Peran Pelaksanaan Perencanaan Supervisi Pendidikan dalam 
Meningkatkan Motivasi dan Kinerja Guru PAI SD di Kecamatan Bancak dan Bringin Kabupaten Semarang Tahun Ajaran 2015/2016. Tesis. Program Pascasarjana. Program Studi Pendidikan Agama Islam. IAIN Salatiga, Jawa Tengah.

Masaong, K. (2012). Supervisi Pembelajaran dan Pengembangan Kapasitas Guru: Memberdayakan Pengawas Sebagai Gurunya Guru. Bandung: Alfabeta.

Moleong, L. J. (2014). Metodologi Penelitian Kualitatif. Bandung: Remaja Rosdakarya.

Mulyasa, E. (2013). Manajemen dan Kepemimpinan Kepala Sekolah. Jakarta: Bumi Aksara.

Muspawi, M., Setiyadi, B., \& Gunawan, G. (2020). Upaya Kepala Sekolah Untuk Peningkatan Kompetensi Profesional Guru. Jurnal Ilmiah Universitas Batanghari Jambi, 20(1), 95103

Parida., Lian, B., dan Sari, A, P. (2020). Implementasi Penilaian Kinerja Guru Berdasarkan Tugas Pokok dan Fungsi Guru melalui Instrumen Supervisi Akademik. Jurnal Pendidikan Tambusai, 4(2).

Rosidi. (2014). Implementasi Aspek Supervisi Akademik Kepala Sekolah pada Proses Pembelajaran di Kecamatan Bulu Kabupaten Temanggung. Tesis. Magister Manajemen Pendidikan Program Pascasarjana FKIP. Universitas Kristen Satya Wacana, Salatiga.

Sugiyono. (2014). Metode Penelitian Pendidikan Pendekatan Kuantitatif, Kualitatif, dan R\&D. Bandung: Alfabeta.

Sugiyono. (2016). Memahami Penelitian Kualitatif. Bandung: Alfabeta

Suharsaputra, U. (2018). Supervisi Pendidikan: Pendekatan Sistem Berbasis Kinerja. Bandung: Refika Aditama.

Zainal, A. (2012). Micro Teaching: Disertai dengan Program Pengenalan Lapangan. Jakarta: Rajawali. 